\title{
Effects of $\mathrm{NO}_{2}$ on Inflorescence Length, Pollen/Seed Amount and Phenolic Metabolites of Common Ragweed (Ambrosia artemisiifolia L.)
}

\author{
Feng Zhao1, Werner Heller'1, Susanne Stich1, Jörg Durner1,2, J. Barbro Winkler³, \\ Claudia Traidl-Hoffmann ${ }^{4,5}$, Dieter Ernst ${ }^{1,5}$, Ulrike Frank ${ }^{1,5 *}$ \\ ${ }^{1}$ Institute of Biochemical Plant Pathology, Helmholtz Zentrum München, Germany, Neuherberg, Germany \\ ${ }^{2}$ Biochemical Plant Pathology, Technische Universität München, Center of Life and Food Sciences Weihenstephan, \\ Freising-Weihenstephan, Germany \\ ${ }^{3}$ Research Unit Environmental Simulation, Helmholtz Zentrum München, München, Germany \\ ${ }^{4}$ Institute of Environmental Medicine, UNIKA-T, Technische Universität München, Augsburg, Germany \\ ${ }^{5}$ CK-CARE, Christine Kühne-Center for Allergy Research and Education, Davos-Wolfgang, Switzerland \\ Email: *ulrike.frank@helmholtz-muenchen.de
}

How to cite this paper: Zhao, F., Heller, W., Stich, S., Durner, J., Winkler, J.B., Traidl-Hoffmann, C., Ernst, D. and Frank, U. (2017) Effects of $\mathrm{NO}_{2}$ on Inflorescence Length, Pollen/Seed Amount and Phenolic Metabolites of Common Ragweed (Ambrosia artemisiifolia L.). American Journal of Plant Sciences, 8, 2860-2870.

https://doi.org/10.4236/ajps.2017.811194

Received: July 6, 2017

Accepted: October 27, 2017

Published: October 30, 2017

Copyright $\odot 2017$ by authors and Scientific Research Publishing Inc. This work is licensed under the Creative Commons Attribution International License (CC BY 4.0).

http://creativecommons.org/licenses/by/4.0/

\begin{abstract}
Ambrosia artemisiifolia L. (common ragweed) is an annual ruderal plant that is native to Northern America but nowadays is also spreading across Europe, and its pollen is known to be highly allergenic. Air pollution, e.g. NOx and climate change may affect the plant growth, pollen production and duration of the entire pollen season. In this study, ragweed plants were grown over an entire vegetation period under $40 \mathrm{ppb} \mathrm{NO}_{2} / \mathrm{clean}$ air (control) and $80 \mathrm{ppb}$ $\mathrm{NO}_{2}$ (treatment). The inflorescence length was not affected by this air pollutant. However, the pollen amount increased, while the seed production decreased in both populations upon elevated $\mathrm{NO}_{2}$ concentrations. Regarding phenolic metabolites elevated $\mathrm{NO}_{2}$ had no effect on the amount of total phenolic metabolites, while individual metabolites showed significant changes.
\end{abstract}

\section{Keywords}

Air Pollution, Ambrosia artemisiifolia, Flavonoids, Pollen, Ragweed, Seeds

\section{Introduction}

Ambrosia artemisiifolia (common ragweed) is native to North America; it is a monoecious and wind-pollinated herbaceous annual plant that belongs to the 
Asteraceae family and has expanded its distribution out of its native range to Europe, Australia, Asia, South Africa and South America [1] [2] [3] [4]. Moreover, for Europe, the models of future expected climate change scenarios indicate a dramatic northward shift of $A$. artemisiifolia, also accompanied by an increase in pollen production [5] [6].

Environmental changes may increase the severity of pollen as stimulated atopic disease by influencing the large-scale distribution and local incidence of allergenic species, the flowering time, the pollen production and the allergenicity of individual pollen grains [7] [8] [9] [10]. It has been shown that elevated $\mathrm{CO}_{2}$ concentrations result in an increase of $A$. artemisiifolia growth and pollen production [9] [10] [11] [12]. In addition to climate change parameters, air pollution might also influence the allergenicity of $A$. artemisiifolia pollen [13] [14] [15] [16]. However, the fumigation of $A$. artemisiifolia plants with $80 \mathrm{ppb} \mathrm{O}_{3}$ did not alter the pollen amount [12]. Atmospheric $\mathrm{NO}_{2}$ is either harmful or beneficial to plants, depending on the concentration and plant species [17] [18] [19] [20] [21]. For the vegetation the critical value is about $15 \mathrm{ppb}$ per year (http://www.umweltbundesamt.de/sites/default/files/medien/1/dokumente/infob latt_stickstoffdioxid.pdf). However, in urban traffic areas up to $90 \mathrm{ppb} \mathrm{NO}_{2}$ can be measured, whereas in rural regions up to $20 \mathrm{ppb}$ can be found (http://www.umweltbundesamt.de/daten/luftbelastung/aktuelle-luftdaten). A reduced pollen viability of Pinus nigra under ambient $\mathrm{NO}_{2}$ levels was found in a field study [22]. Similarly in vitro fumigation of pollen from three tree species reduced the viability and germination [23]. The in vitro fumigation of pollen with $\mathrm{NO}_{2}$ did not induce new allergens in birch or $A$. artemisiifolia and had no effect on the allergen release from grass pollen [24] [25]. Using high concentrations of $\mathrm{NO}_{2}$ (ppm range), the content of several Phleum pratense grass allergens (Phl p) decreased [26]. However, treatment of pollen from four different tree species with moderate $\mathrm{NO}_{2}$ concentrations (40 - $300 \mathrm{ppb}$ ) resulted in greater immunoglobulin E (IgE) recognition by immunodetection [23] [27]. Pollen isolated from $A$. artemisiifolia that was fumigated with realistic $\mathrm{NO}_{2}$ concentrations $(80 \mathrm{ppb})$ also showed a higher IgE recognition [16]. Similarly $\mathrm{NO}_{2}$-fumigated pollen of $P$. pratense stimulated the production of chemokines by an increased Th2-cell response in human cells [28]. These studies suggest that changes in $\mathrm{NO}_{2}$ concentrations will affect the allergenic potential of pollen and play a role in human health diseases that are related to allergic rhinitis and asthma.

Flavonoids are important secondary metabolites that protect pollen from UV-B irradiation, especially during the long-distance transport [29]. In addition, flavonoids are crucial for the germination process in many plant species [30] [31]. Moreover, these compounds may also be involved in the allergenic response of pollen [32] [33]. Flavonoids can interact with allergens [34] [35], and a direct link between the binding of a quercetin glycoside to Bet $\mathrm{v} 1$ and the inflammation responses was recently reported [36].

From these perspectives, a detailed analysis of the allergenic pollen and seed 
production would allow to understand the anticipated changes in the pollen amount and seed dispersal in response to elevated $\mathrm{NO}_{2}$ concentrations. In previous studies, we had shown that elevated levels of $\mathrm{O}_{3}$ had no effect on the pollen production of $A$. artemisiifolia, whereas $\mathrm{CO}_{2}$ increased and drought decreased the pollen amount [12]. In this study, we altered the gaseous air pollution by linking the pollen and seed production of $A$. artemisiifolia with elevated $\mathrm{NO}_{2}$ levels. We emphasize that this environmental change affects the pollen amount, as well as phenolic metabolites, which is relevant to human health.

\section{Material and Methods}

\subsection{Plant Growth Conditions}

A. artemisiifolia seeds were collected from a single plant at an outdoor stand (Bad Waldsee, Baden-Württemberg, Germany) to prevent epigenetic-caused effects [37]. Seeds were sown in standard soil (Floradur', Bayerische Gärtnerei Genossenschaft, München, Germany) in small multiflor palettes $(6 \times 6 \mathrm{~cm})$ and transferred into four Plexiglas sub-chambers $(1.1 \mathrm{~m} \times 0.9 \mathrm{~m} \times 0.8 \mathrm{~m})$ that were placed in Phytotron walk-in chambers [38]

(http://www.helmholtz-muenchen.de/en/eus/facilities/phytotron/index.html). All physical parameters, including the wind velocity were identical in the sub-chambers. After germination, the seedlings were planted in pots $(\varnothing 17 \mathrm{~cm})$. One plant was grown per pot and 10 pots were placed into the sub-chambers. Plant growth and $\mathrm{NO}_{2}$ fumigation were performed as described by [16]. Briefly, plants were treated with $40 \mathrm{ppb} \mathrm{NO}$ (control) or $80 \mathrm{ppb} \mathrm{NO}$ (treatment) for 61 $\mathrm{d}(10 \mathrm{~h} / \mathrm{d})$, and pollen was harvested during the last $28 \mathrm{~d}$ of fumigation $\left(1^{\text {st }}\right.$ population), using a modified ARACON system (BETATECH, Ghent, Belgium) that covered the male inflorescences (Figure 1). Five inflorescences from each plant were randomly selected for the sampling of the pollen. The collected pollen

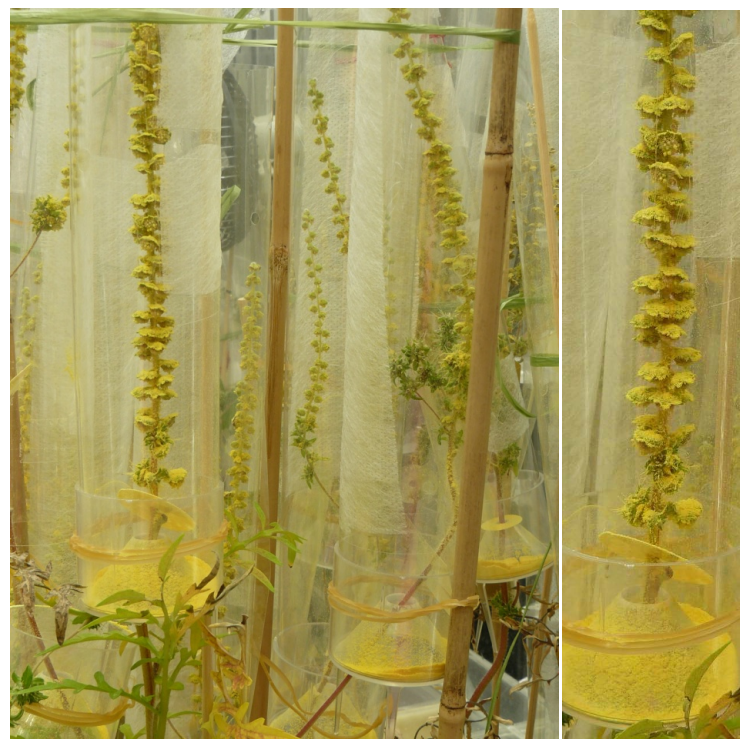

Figure 1. Sampling of ragweed pollen using a modified ARACON system. 
samples were stored at $-80^{\circ} \mathrm{C}$. In addition, seeds from the $40 \mathrm{ppb} \mathrm{NO}$ treatment were collected and used in a second experiment the following year $\left(2^{\text {nd }}\right.$ population). For technical reasons (an additional ozone experiment was carried out) the second population was treated with clean air (control) and $80 \mathrm{ppb} \mathrm{NO}_{2}$ (treatment) [16]. For each population morphological data like inflorescence length, the pollen and seed amount was measured.

\subsection{Analysis of Phenolic Metabolites}

Frozen pollen $(15 \mathrm{mg})$ was extracted with $1.5 \mathrm{ml}$ of phosphate buffer saline (PBS) for $1 \mathrm{~h}$ at room temperature. After centrifugation, the PBS supernatant was kept, and the residue was re-extracted with $1.5 \mathrm{ml}$ of methanol (high-performance liquid chromatography (HPLC) grade). The reverse-phase high-performance liquid chromatography (RP-HPLC) (Beckman HPLC System Gold, Beckman, Munich, Germany; column $240 \times 4.5 \mathrm{~mm}$ ProntosilSpheribondODS2, NC, $5 \mu \mathrm{m}$, Bischoff, Leonberg, Germany) of both extracts was performed as described by [39], using $10 \mu \mathrm{l}$ of PBS samples. In the case of the methanol extraction, $25 \mu \mathrm{l}$ of $\mathrm{H}_{2} \mathrm{O}$ was added to $75 \mu \mathrm{l}$ of the methanolic samples, then centrifuged, and $10 \mu \mathrm{l}$ were used for RP-HPLC separation. Solvents and gradient conditions for RP-HPLC separations were as described by [39]. Detection was at $280 \mathrm{~nm}$ with a UV/visible diode-array detector (Beckman Model 168).

\subsection{Statistics}

To calculate significant differences between samples, an unpaired t-test was carried out. The Shapiro-Wilk normality test or the Mann-Whitney rank sum test was used (SigmaPlot 12; Systat Software, Erkrath, Germany).

\section{Results and Discussion}

\subsection{Morphological Plant Growth and Pollen Data}

Regarding morphological parameters, increased $\mathrm{NO}_{2}$ had no effect on the inflorescence length (Table 1), which is similar to the air pollution $\mathrm{O}_{3}$, also showing no effect on this parameter, whereas elevated $\mathrm{CO}_{2}$ resulted in an increased length of the main inflorescence [12]. Regarding allergenicity, the pollen amount clearly increased in both years of the study by approximately 70 to $80 \%$ (Table 1 ). This result parallels the increased number of flowers found in tomato plants upon $\mathrm{NO}_{2}$ fumigation [40]. The increased pollen amount in A. artemisiifolia, similar to that under elevated $\mathrm{CO}_{2}[12]$, may result in a higher pollen concentration in the air, with expected negative effects on the atopic population [41]. The total seed production and seed amount clearly decreased under elevated $\mathrm{NO}_{2}$ (Table 1). This may be caused by a reduced pollen viability and germination rate upon $\mathrm{NO}_{2}$ exposure [22] [23]. An important point for seed production in ragweed is the plant density [42]. As the plant density was the same in all sub-chambers the seed production could only be influenced by $\mathrm{NO}_{2}$. This result is in contrast to 
Table 1. Morphological data of ragweed plants that were grown in exposure chambers and fumigated with elevated $\mathrm{NO}_{2}$ concentrations.

\begin{tabular}{ccccc}
\hline $\mathrm{NO}_{2}(\mathrm{ppb})$ & $\begin{array}{c}\text { Inflorescence } \\
(\mathrm{cm}) \pm \mathrm{SD}\end{array}$ & $\begin{array}{c}\text { Pollen/Inflorescence } \\
(\mathrm{mg}) \pm \mathrm{SD}\end{array}$ & $\begin{array}{c}\text { Seeds/plant } \\
(\mathrm{mg}) \pm \mathrm{SD}\end{array}$ & $\begin{array}{c}\text { Weight of } 50 \text { grains } \\
(\mathrm{mg}) \pm \mathrm{SD}\end{array}$ \\
\hline $1^{\text {st }} 40$ & $23.73 \pm 1.12$ & $79 \pm 6$ & $1329 \pm 85$ & $229 \pm 18$ \\
$1^{\text {st }} 80$ & $25.18 \pm 1.57$ & $132 \pm 11$ & $905 \pm 69$ & $199 \pm 10$ \\
$\mathrm{p}$-value & 0.327 & $1.8 \times 10 \mathrm{E}^{-5 *}$ & $2.3 \times 10 \mathrm{E}^{-3 *}$ & $1.9 \times 10 \mathrm{E}^{-3 *}$ \\
$2^{\text {nd }} 0$ & $24.48 \pm 1.35$ & $85 \pm 8$ & $1637 \pm 77$ & $237 \pm 16$ \\
$2^{\text {nd }} 80$ & $24.61 \pm 1.77$ & $159 \pm 12$ & $1024 \pm 53$ & $209 \pm 9$ \\
p-value & 0.568 & $2.7 \times 10 \mathrm{E}^{-5 *}$ & $3.5 \times 10 \mathrm{E}^{-3 *}$ & $2.9 \times 10 \mathrm{E}^{-3 *}$ \\
\hline
\end{tabular}

Number of plants $\mathrm{N}=20,5$ inflorescences per plant, t-test, ${ }^{*} \mathrm{p}$-value $<0.05$. Five inflorescences from each plant were randomly selected.

black turtle bean (Phaseolus vulgaris), which showed an increased seed number and seed weight [19].

\subsection{Secondary Metabolites}

The total amount of analyzed phenolics is shown in Figure 2(a). However, no significant changes between the controls and treatments in either year were evident. This result is similar to that of $A$. artemisiifolia plants that were fumigated with ozone or elevated $\mathrm{CO}_{2}$ or were grown under drought stress [14] [43]. Typical RP-HPLC diagrams of water-soluble extracts revealed six prominent compounds (Figure 3(a)). Diode array spectra of the respective peaks indicated compounds DA 1,2, 4 and 6 as quercetin derivatives and compound DA 5 as a kaempferol derivative, whereas compound DA3 could not be identified (Figure $3(\mathrm{~b})$, Figure 3(c)), and the highest amounts were found for DA 2, 5 and 6 (Figure 2(b)). Methanol-extractable phenolics additionally also showed six compounds that were characterized as hydroxycinnamic amides according to their diode-array spectra (Figure 3(d), Figure 3(e)). Significant changes with an increased amount were only observed in the $2^{\text {nd }}$ population for the water-soluble metabolite DA 6 and the methanol-extractable metabolites DA 5 and 6 (Figure 2 (b)). In contrast, in the $1^{\text {st }}$ population, the water-soluble metabolites of DA 1 and 4 clearly decreased under elevated $\mathrm{NO}_{2}$ (Figure 2(b)). These differences might be explained by the different control treatments in both years: $40 \mathrm{ppb} \mathrm{NO}_{2}$ in the first year and clean air in the second year. Changes in individual phenolic metabolites have also been reported in $A$. artemisiifolia pollen upon $\mathrm{CO}_{2}$ and/or drought stress [43], whereas no changes were observed upon ozone fumigation [14]. The pollen of several other plants species that were sampled from polluted and less-polluted areas showed an increased amount of individual flavonoids [44] [45]. These data indicate that individual stress will differentially affect the flavonoid composition. As we did not find significant differences in the total flavonoid amount, it is unlikely that there is a direct effect of flavonoids on IgE 


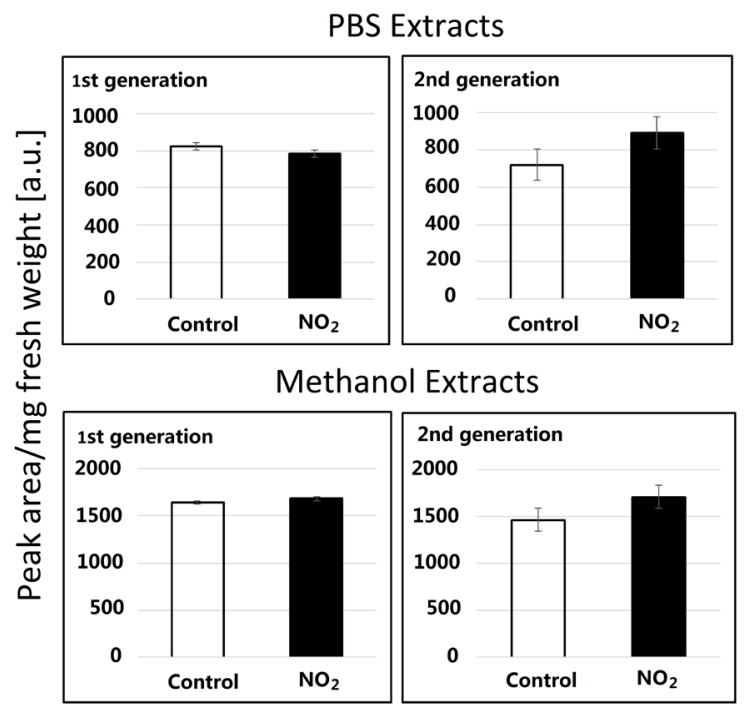

(a)
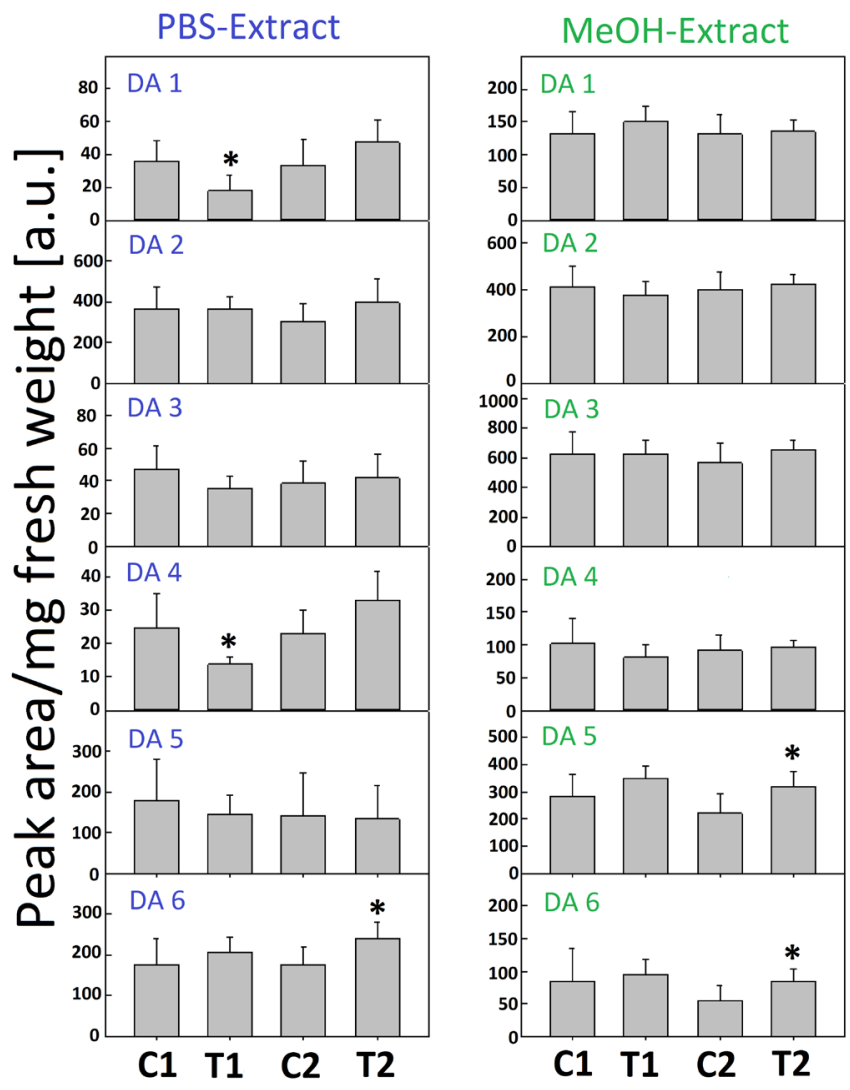

(b)

Figure 2. (a) Total amount of water-soluble and methanol-extractable phenolic metabolites in ragweed pollen. The separation was performed by RP-HPLC. Plants were fumigated with $40 \mathrm{ppb} \mathrm{NO} \mathrm{N}_{2} 1^{\text {st }}$ control) or clean air (2 ${ }^{\text {nd }}$ control) or with $80 \mathrm{ppb} \mathrm{NO}_{2}\left(1^{\text {st }}\right.$ and $2^{\text {nd }}$ treatment); bars indicate $\pm \mathrm{SD} ; \mathrm{N}=8$ plants, 5 inflorescences per plant). (b) Amount of individual PBS-soluble and methanol-extractable phenolic metabolites in pollen of $A$. artemisiifolia. $\mathrm{C} 1=1^{\text {st }}$ population of control; $\mathrm{T} 1=1^{\text {st }}$ population of treatment; $\mathrm{C} 2=2^{\text {nd }}$ population of control; $\mathrm{T} 2=2^{\text {nd }}$ population of treatment. The bars indicate $\pm \mathrm{SD}$ and significant differences are indicated by asterisks $\left(\mathrm{N}=8\right.$ plants, 5 inflorescences per plant; t-test, ${ }^{*} \mathrm{p}$-value $\left.<0.05\right)$.

recognition, as elevated $\mathrm{NO}_{2}$ resulted in a higher IgE recognition in immunoblots [16]. However, flavonoids can play a modulating role on immunity and inflammation [46] and may influence membrane translocation of allergens [47].

\section{Conclusion}

Our data on $A$. artemisiifolia fumigated with elevated $\mathrm{NO}_{2}$ support the hypothesis that the overall allergenicity might be increased by an increased pollen amount. However, differences in the estimation of allergen exposure between pollen amount and ELISA data must be considered [48] [49]. As the overall seed production decreased under elevated $\mathrm{NO}_{2}$, the dispersal of $A$. artemisiifolia should not be affected by this air pollutant.

\section{Acknowledgements}

This work was supported by grant 3/09 CK-CARE, Christine-Kühne Center for Allergy Research and Education and the China Scholarship Council. We gratefully 

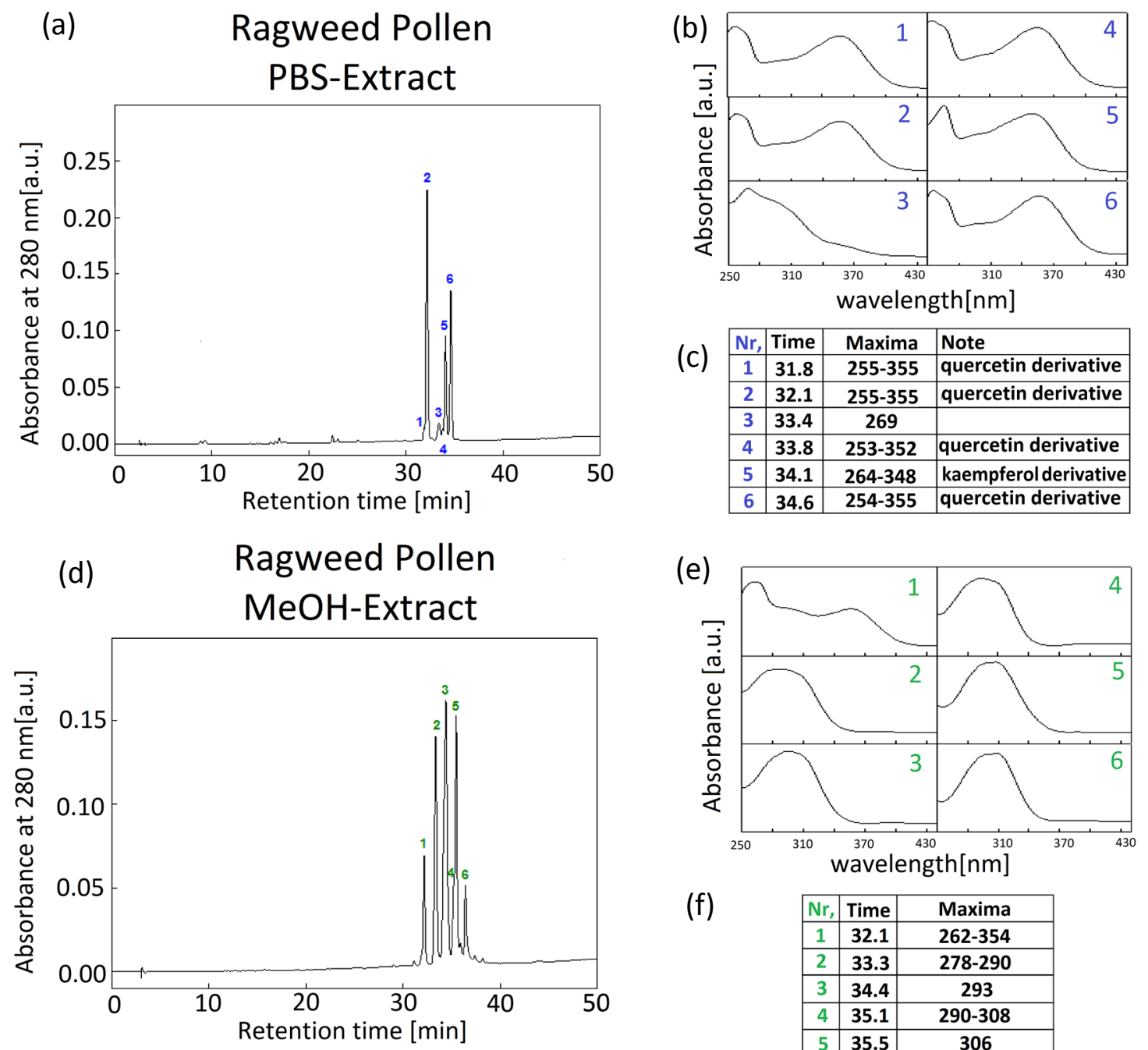

(f) $\quad$\begin{tabular}{|c|c|c|}
\hline $\mathrm{Nr}$, & Time & Maxima \\
\hline 1 & 32.1 & $\mathbf{2 6 2 - 3 5 4}$ \\
\hline 2 & 33.3 & $\mathbf{2 7 8 - 2 9 0}$ \\
\hline 3 & $\mathbf{3 4 . 4}$ & $\mathbf{2 9 3}$ \\
\hline 4 & $\mathbf{3 5 . 1}$ & $\mathbf{2 9 0 - 3 0 8}$ \\
\hline 5 & $\mathbf{3 5 . 5}$ & $\mathbf{3 0 6}$ \\
\hline 6 & $\mathbf{3 6 . 5}$ & $\mathbf{2 9 7 - 3 0 7}$ \\
\hline
\end{tabular}

Figure 3. RP-HPLC diagram of water-soluble and methanol-extractable phenolic metabolites. (a) shows a typical HPLC run of a PBS extract from $A$. artemisiifolia pollen at an absorbance of $280 \mathrm{~nm}$, resulting in 6 distinct peaks; (b) represents the diode array spectra of the respective peaks between 250 and $430 \mathrm{~nm}$; (c) indicates the elution times and maxima of the corresponding peaks, and preliminary structural assignments are given; (d) gives a typical HPLC run of a methanol extract, following the PBS extraction, from $A$. artemisiifolia pollen at an absorbance of $280 \mathrm{~nm}$. The HPLC run resulted in six distinct peaks; (e) diode array spectra of the respective peaks between 250 and $430 \mathrm{~nm}$; (f) indicates the corresponding retention time and the peak maxima for each single peak.

acknowledge the excellent support of $\mathrm{NO}_{2}$ fumigation by Hans Lang and technical support by Elke Gerstner and Barbara Groß. The A. artemisiifolia seeds were kindly provided by Beate Alberternst (Friedberg).

\section{Conflict of Interest}

The authors declare no conflicts of interest regarding the publication of this paper.

\section{References}

[1] McFadyen, R.E. and Weggler-Beaton, K. (2000) The Biology and Host Specificity of Liothrips sp. (Thysanoptera: Phlaeothripidae), an Agent Rejected for Biocontrol of 
Annual Ragweed. Biological Control, 19, 105-111. https://doi.org/10.1006/bcon.2000.0851

[2] Xu, H., Qiang, S., Han, Z., Guo, J., Huang, Z., Sun, H., He, S., Ding, H., Wu, H. and Wan, F. (2006) The Status and Causes of Alien Species Invasion in China. Biodiversity and Conservation, 15, 2893-2904. https://doi.org/10.1007/s10531-005-2575-5

[3] Cunze, S., Leiblein, M.C. and Tackenberg, O. (2013) Range Expansion of Ambrosia artemisiifolia in Europe Is Promoted by Climate Change. ISRN Ecology, 2013, Article ID: 610126.

[4] GISD (2014) Ambrosia artemisiifolia. http://www.issg.org/database/species/ecology.asp? si=1125\&fr=1121\&sts=sss\&lang= $\underline{\mathrm{EN}}$

[5] Storkey, J., Stratonovitch, P., Chapman, D.S., Vidotto, F. and Semenov, M.A. (2014) A process-Based Approach to Predicting the Effect of Climate Change on the Distribution of an Invasive Allergenic Plant in Europe. PloS One, 9, e88156.

https://doi.org/10.1371/journal.pone.0088156

[6] Hamaoui-Laguel, L., Vautard, R., Liu, L., Solmon, F., Viovy, N., Khvorosthyanov, D., Essl, F., Chuine, I., Colette, A., Semenov, M.A., Schaffhauser, A., Storkey, J. Thibaudon, M. and Epstein, M.M. (2015) Effects of Climate Change and Seed Dispersal on Airborne Ragweed Pollen Loads in Europe. Nature Climate Change, 5, 766-771. https://doi.org/10.1038/nclimate2652

[7] Behrendt, H. and Becker, W.-M. (2001) Localization, Release and Bioavailability of Pollen Allergens: The Influence of Environmental Factors. Current Opinion in Immunology, 13, 709-715. https://doi.org/10.1016/S0952-7915(01)00283-7

[8] Traidl-Hoffmann, C., Kasche, A., Menzel, A., Jakob, T., Thiel, M., Ring, J. and Behrendt, H. (2003) Impact of Pollen on Human Health: More than Allergen Carriers? International Archives of Allergy and Immunology, 131, 1-13. https://doi.org/10.1159/000070428

[9] Rogers, C.A., Wayne, P.M., Macklin, E.A., Muilenberg, M.L., Wagner, C.J., Epstein, P.R. and Bazzaz, F.A. (2006) Interaction of the Onset of Spring and Elevated Atmospheric $\mathrm{CO}_{2}$ on Ragweed (Ambrosia artemisiifolia L.) Pollen Production. Environmental Health Perspectives, 114, 865-869. https://doi.org/10.1289/ehp.8549

[10] Ziska, L.H., Epstein, P.R. and Rogers, C.A. (2008) Climate Change, Aerobiology, and Public Health in the Northeast United States. Mitigation and Adaptation Strategies for Global Change, 13, 607-613. https://doi.org/10.1007/s11027-007-9134-1

[11] Stinson, K.A. and Bazzaz, F.A. (2006) $\mathrm{CO}_{2}$ Enrichment Reduces Reproductive Dominance in Competing Stands of Ambrosia artemisiifolia (Common Ragweed). Oecologia, 147, 155-163. https://doi.org/10.1007/s00442-005-0250-X

[12] ElKelish, A., Winkler, J.B., Lang, H., Holzinger, A., Behrendt, H., Durner, J., Kanter, U. and Ernst, D. (2014) Effects of Ozone, $\mathrm{CO}_{2}$ and Drought Stress on the Growth and Pollen Production of Common Ragweed (Ambrosia artemisiifolia). Julius-Kühn-Archiv, 445, 139-147.

[13] Ghiani, A., Aina, R., Asero, R., Bellotto, E. and Citterio, S. (2012) Ragweed Pollen Collected along High-Traffic Roads Shows a Higher Allergenicity than Pollen Sampled in Vegetated Areas. Allergy, 67, 887-894.

https://doi.org/10.1111/j.1398-9995.2012.02846.x

[14] Kanter, U., Heller, W., Durner, J., Winkler, J.B., Engel, M., Behrendt, H., Holzinger, A., Braun, P., Hauser, M., Ferreira, F., Mayer, K., Pfeifer, F. and Ernst, D. (2013) Molecular and Immunological Characterization of Ragweed (Ambrosia artemisiifolia L.) Pollen after Exposure of the Plants to Elevated Ozone over a Whole Growing 
Season. PloS One, 8, e61518. https://doi.org/10.1371/journal.pone.0061518

[15] Frank, U., Elkelish, A., Zhao, F., Durner, J., Winkler, J.B., Behrendt, H., Traidl-Hoffmann, C., von Törne, C., Hauck, S.M. and Ernst, D. (2014) Ragweed (Ambrosia artemisiifolia) Pollen Allergenicity: Proteome Analysis upon Elevated $\mathrm{CO}_{2}$ and Drought Stress Ambroisie, 29, 32-43.

[16] Zhao, F., Elkelish, A., Durner, J.C.L., Winkler, J.B., Ruëff, F., Behrendt, H., Traidl-Hoffmann, C., Holzinger, A., Kofler, W., Braun, P., von Toerne, C., Hauck, S.M., Ernst, D. and Frank, U. (2016) Common Ragweed (Ambrosia artenisiifolia L.): Allergenicity and Molecular Characterization of Pollen after Plant Exposure to Elevated $\mathrm{NO}_{2}$. Plant, Cell \& Environment, 39, 147-164.

https://doi.org/10.1111/pce.12601

[17] Capron, T.M. and Mansfield, T.A. (1977) Inhibition of Growth in Tomato by Air Polluted with Nitrogen Oxides. Journal of Experimental Botany, 28, 112-116. https://doi.org/10.1093/jxb/28.1.112

[18] Kress, L.W. and Skelly, J.M. (1982) Response of Several Eastern Forest Tree Species to Chronic Doses of Ozone and Nitrogen Dioxide. Plant Disease, 66, 1149-1152. https://doi.org/10.1094/PD-66-1149

[19] Sandhu, R. and Gupta, G. (1989) Effects of Nitrogen Dioxide on Growth and Yield of Black Turtle Bean (Phaseolus vulgaris L.) cv. 'Domino'. Environmental Pollution, 59, 337-344. https://doi.org/10.1016/0269-7491(89)90160-7

[20] Wellburn, A.R. (1990) Tansley Review No. 24 Why Are Atmospheric Oxides of Nitrogen Usually Phytotoxic and Not Alternative Fertilizers? New Phytologist, 115, 395-429. https://doi.org/10.1111/j.1469-8137.1990.tb00467.x

[21] Honour, S.L., Bell, J.N.B., Ashenden, T.W., Cape, J.N. and Power, S.A. (2009) Responses of Herbaceous Plants to Urban Air Pollution: Effects on Growth, Phenology and Leaf Surface Characteristics. Environmental Pollution, 157, 1279-1286. https://doi.org/10.1016/j.envpol.2008.11.049

[22] Gottardini, E., Cristofori, A., Cristofolini, F., Maccherini, S. and Ferretti, M. (2008) Ambient Levels of Nitrogen Dioxide $\left(\mathrm{NO}_{2}\right)$ May Reduce Pollen Viability in Austrian Pine (Pinus nigra Arnold) Trees-Correlative Evidence from a Field Study. Science of the Total Environment, 402, 299-305.

https://doi.org/10.1016/j.scitotenv.2008.04.048

[23] Cuinica, L.G., Abreu, I. and da Silva, J.E. (2014) Effect of Air Pollutant $\mathrm{NO}_{2}$ on $B e-$ tula pendula, Ostrya carpinifolia and Carpinus betulus Pollen Fertility and Human Allergenicity. Environmental Pollution, 186, 50-55. https://doi.org/10.1016/j.envpol.2013.12.001

[24] Behrendt, H., Becker, W.M., Fritzsche, C., Sliwa-Tomczok, W., Tomczok, J., Friedrichs, K.H. and Ring, J. (1997) Air Pollution and Allergy: Experimental Studies on Modulation of Allergen Release from Pollen by Air Pollutants. International Archives of Allergy and Immunology, 113, 69-74. https://doi.org/10.1159/000237511

[25] Aina, R., Berra, E., Marino, G., Pastorello, E.A. and Citterio, S. (2007) Proteomic Analysis of Birch and Ragweed Pollen Artificially Exposed to $\mathrm{NO}_{2}$. World Allergy Organization Journal, S198-S199. https://doi.org/10.1097/01.WOX.0000301890.70413.51

[26] Rogerieux, F., Godfrin, D., Senechal, H., Motta, A.C., Marliere, M., Peltre, G. and Lacroix, G. (2007) Modifications of Phleum pratense Grass Pollen Allergens Following Artificial Exposure to Gaseous Air Pollutants $\left(\mathrm{O}_{3}, \mathrm{NO}_{2}, \mathrm{SO}_{2}\right)$. International Archives of Allergy and Immunology, 143, 127-134.

https://doi.org/10.1159/000099079 
[27] Sousa, R., Duque, L., Duarte, A.J., Gomes, C.R., Ribeiro, H., Cruz, A., Esteves da Silva, J. and Abreu, I. (2012) In Vitro Exposure of Acer negundo Pollen to Atmospheric Levels of $\mathrm{SO}_{2}$ and $\mathrm{NO}_{2}$ : Effects on Allergenicity and Germination. Environmental Science \& Technology, 46, 2406-2412. https://doi.org/10.1021/es2034685

[28] Chassard, G., Choel, M., Gosselin, S., Vorng, H., Petitprez, D., Shahali, Y., Tsicopoulos, A. and Visez, N. (2015) Kinetic of $\mathrm{NO}_{2}$ Uptake by Phleum pratense Pollen: Chemical and Allergenic Implications. Environmental Pollution, 196, 107-113. https://doi.org/10.1016/j.envpol.2014.10.004

[29] Flenley, J.R. (2011) Why Is Pollen Yellow? And Why Are There So Many Species in the Tropical Rain Forest? Journal of Biogeography, 38, 809-816. https://doi.org/10.1111/j.1365-2699.2011.02480.x

[30] Mo, Y., Nagel, C. and Taylor, L.P. (1992) Biochemical Complementation of Chalcone Synthase Mutants Defines a Role for Flavonols in Functional Pollen. Proceedings of the National Academy of Sciences of the United States of America, 89, 7213-7217. https://doi.org/10.1073/pnas.89.15.7213

[31] Shirley, B.W. (1996) Flavonoid Biosynthesis: 'New' Functions for an 'Old' Pathway. Trends in Plant Science, 1, 377-382.

[32] Berrens, L., de la Cuadra, B. and Gallego, M.T. (1997) Complement Inactivation by Allergenic Plant Pollen Extracts. Life Sciences, 60, 1497-1503. https://doi.org/10.1016/S0024-3205(97)00101-X

[33] Yoon, M.-S., Lee, J.S., Choi, B.-M., Jeong, Y.-I., Lee, C.-M., Park, J.-H., Moon, Y., Sung, S.-C., Lee, S.K., Chang, Y.H., Chung, H.Y. and Park, Y.-M. (2006) Apigenin Inhibits Immunostimulatory Function of Dendritic Cells: Implication of Immunotherapeutic Adjuvant. Molecular Pharmacology, 70, 1033-1044. https://doi.org/10.1124/mol.106.024547

[34] Mogensen, J.E., Wimmer, R., Larsen, J.N., Spangfort, M.D. and Otzen, D.E. (2002) The Major Birch Allergen, Bet v 1, Shows Affinity for a Broad Spectrum of Physiological Ligands. The Journal of Biological Chemistry, 277, 23684-23692. https://doi.org/10.1074/jbc.M202065200

[35] Koistinen, K.M., Soininen, P., Venäläinen, T.A., Häyrinen, J., Laatikainen, R., Peräkylä, M., Tervahauta, A.I. and Kärenlampi, S.O. (2005) Birch PR-10c Interacts with Several Biologically Important Ligands. Phytochemistry, 66, 2524-2533. https://doi.org/10.1016/j.phytochem.2005.09.007

[36] Seutter von Loetzen, C., Hoffmann, T., Hartl, M.J., Schweimer, K., Schwab, W., Rösch, P. and Hartl-Spiegelhauer, O. (2014) Secret of the Major Birch Pollen Allergen Bet v 1: Identification of the Physiological Ligand. Biochemical Journal, 457, 379-390. https://doi.org/10.1042/BJ20130413

[37] Elwell, A.L., Gronwall, D.S., Miller, N.D., Spalding, E.P. and Durham Brooks, T.L. (2011) Separating Parental Environment from Seed Size Effects on Next Generation Growth and Development in Arabidopsis. Plant, Cell \& Environment, 34, 291-301. https://doi.org/10.1111/j.1365-3040.2010.02243.x

[38] Thiel, S., Döhring, T., Köfferlein, M., Kosak, A., Martin, P. and Seidlitz, H.K. (1996) A Phytotron for Plant Stress Research: How Far Can Artificial Lighting Compare to Natural Sunlight? Journal of Plant Physiology, 148, 456-463. https://doi.org/10.1016/S0176-1617(96)80279-3

[39] Ghirardo, A., Heller, W., Fladung, M., Schnitzler, J.-P. and Schroeder, H. (2012) Function of Defensive Volatiles in Pedunculate Oak (Quercus robur) Is Tricked by the Moth Tortrix viridana. Plant, Cell \& Environment, 35, 2192-2207. https://doi.org/10.1111/j.1365-3040.2012.02545.x 
[40] Takahashi, M., Sakamoto, A., Ezura, H. and Morikawa, H. (2011) Prolonged Exposure to Atmospheric Nitrogen Dioxide Increases Fruit Yield of Tomato Plants. Plant Biotechnology, 28, 485-487. https://doi.org/10.5511/plantbiotechnology.11.0819a

[41] D'Amato, G. and Cecchi, L. (2008) Effects of Climate Change on Environmental Factors in Respiratory Allergic Diseases. Clinical and Experimental Allergy, 38, 1264-1274. https://doi.org/10.1111/j.1365-2222.2008.03033.x

[42] Friedmann, J. and Barrett, S.C.H. (2008) High Outcrossing in the Annual Colonizing Species Ambrosia artemisiifolia (Asteraceae). Annals of Botany, 101, 1303-1309. https://doi.org/10.1093/aob/mcn039

[43] ElKelish, A., Zhao, F., Heller, W., Durner, J., Winkler, J., Behrendt, H., Traidl-Hoffmann, C., Horres, R., Pfeifer, M., Frank, U. and Ernst, D. (2014) Ragweed (Ambrosia artemisiifolia) Pollen Allergenicity: SuperSAGE Transcriptomic Analysis upon Elevated $\mathrm{CO}_{2}$ and Drought Stress. BMC Plant Biology, 14, 176. https://doi.org/10.1186/1471-2229-14-176

[44] Rezanejad, F. (2009) Air Pollution Effects on Structure, Proteins and Flavonoids in Pollen Grains of Thuja orientalis L. (Cupressaceae). Grana, 48, 205-213. https://doi.org/10.1080/00173130902949417

[45] Rezanejad, F. (2012) Air Pollution Effects on Flavonoids in Pollen Grains of Some Ornamental Plants. Turkish Journal of Botany, 36, 49-54.

[46] Chirumbolo, S. (2010) The Role of Quercetin, Flavonols and Flavones in Modulating Inflammatory Cell Function. Inflammation \& Allergy-Drug Targets, 9, 263-285. https://doi.org/10.2174/187152810793358741

[47] Mogensen, J.E., Ferreras, M., Wimmer, R., Petersen, S.V., Enghild, J.J. and Otzen, D.E. (2007) The Major Allergen from Birch Tree Pollen, Bet v 1, Binds and Permeabilizes Membranes. Biochemistry, 46, 3356-3365. https://doi.org/10.1021/bi062058h

[48] Buters, J.T.M., Kasche, A., Weichenmeier, I., Schober, W., Klaus, S., Traidl-Hoffmann, C., Menzel, A., Huss-Marp, J., Krämer, U. and Behrendt, H. (2008) Year-to-Year Variation in Release of Bet v 1 Allergen from Birch Pollen: Evidence for Geographical Differences between West and South Germany. International Archives of Allergy and Immunology, 145, 122-130. https://doi.org/10.1159/000108137

[49] Buters, J.T.M., Weichenmeier, I., Ochs, S., Pusch, G., Kreyling, W., Boere, A.J.F., Schober, W. and Behrendt, H. (2010) The Allergen Bet v 1 in Fractions of Ambient Air Deviates from Birch Pollen Counts. Allergy, 65, 850-858.

https://doi.org/10.1111/j.1398-9995.2009.02286.x 